\title{
УКРАЇНСЬКІ КОМПОЗИТОРИ І ВОКАЛІСТИ У СВІТІ НОВОГО ПРОЕКТНОГО ОПЕРОТВОРЕННЯ
}

\section{Сфіменко А. Г.}

\section{ВСТУП}

На питання, яку роль в історії музичного театру відігравали оперні співаки, яких статусу і соціального ангажементу очікувала від них держава, яких мистецьких вершин сягала їхня майстерність, яку функцію вони мали в оперних постановках, зможуть легко відповісти не лише спеціалісти, а й меломани. Яка ж перспектива очікує оперних співаків нині, особливо в театрально-музичних проєктах майбутнього, поки що невідомо нікому. А це суттєве питання турбує вокалістів, задіяних у класичному оперному репертуарі. Розмаїття постмодерних мутацій жанру притягує увагу музикознавців, але теорія не завжди встигає за музично-сценічною практикою.

Група науковців - авторів проєкту «Майбутнє опери: на межі герменевтики і перформативності» (Дірк Бекер, Еріка Фішер-Ліхте, Карл Гегеман, Крістіне Лемке-Матвей та ін.), що проводився в Університеті мистецтв Граца під керівництвом Барбари Бейєр, - опитували запрошених митців і журналістів (Вера Немірова, Клара Гінтербергер, Піа Пальме, Навід Кермані, Штефан Мьош, Ульріх Рунке, Міхаель Гофштеттер та ін.) із метою змоделювали «ситуацію майбутнього опери». Центральний об’єкт науково-практичного дослідження (сучасна оперна практика) супроводжувався експериментальними проєктами 3 фокусом на різних режисерських версіях Cosi fan tutte B.А. Моцарта на сцені Deutsche Oper Berlin (2013). Предметом подіум-дискусій були нові модуси комунікації режисерів і вокалістів у роботі над інтерпретаціями оперної класики. Проводилися практичні семінари і відкриті репетиції. Завершився проєкт науковим симпозіум. Результати дослідження були опубліковані у 2014 році в колективній монографії «Майбутнє опери: на межі герменевтики і перформативності» в серії видавництва Theater der Zeit. Recherchen $113^{1}$.

У цьому проєкті увагу привернуло дослідження змін сценічного амплуа вокалістів у ситуації оперативного Regietheater. Згадаймо суть

${ }^{1}$ Die Zukunft der Oper. Zwischen Hermeneutik und Performativität. Herausgegeben von Barbara Beyer, Susanne Kogler und Roman Lemberg. Berlin: Theater der Zeit. Recherchen 113. 430 S. ISBN 978-3-943881-88-2. 
«Прощання 3 Оперою Іванівною» від оперного експерта Олексія Паріна: «Сучасний музичний театр виникає там, де опера починає приховувати своє музичне нутро» ${ }^{2}$. До аспектів вивчення постаті вокаліста-актора в комплексі «голосових елементів (висота голосу, тембр, сила, темп тощя)» додалася тріада театральних характеристик міміка-жест-поза ${ }^{3}$. Як зауважує Я. Іваницька, «ці елементи [ред. вистави] можуть бути паралельні один одному, можуть розходитися так, що їхня взаємодія відчувається як послідовна чи симультанна інтерференція» ${ }^{4}$. Зауважимо, що із семіотичної позиції українська дослідниця вивчає в поведінці вокалістів «рухи тіла, котрими висловлюється і на котрих засноване відношення актора до сиенічного nростору» ${ }^{5}$. Отже, оперний вокаліст-актор виступає «ланкою, яка стає значущою лише в загальній структурі сценічної постановки. Співак опиняється в центрі полісемантичних стосунків: актор - сценічний простір, актор - музично-драматичний текст, актор - інші актори» ${ }^{6}$.

Отже, з одного боку, вимоги до оперних співаків зросли, з іншого інтерес сучасних композиторів до оперних голосів поступово знижується. Проте радикальні квазіоперні проєкти молодих митців викликають науковий інтерес і відкривають нові ракурси дослідження опери як полісемантичного феномена ${ }^{7}$.

Поки дослідники прогнозують, яким бути музичному театру майбутнього, зокрема: 1) як перформативність змінює майбутні вимоги і очікування до оперних артистів, 2) від яких факторів залежать рівень зацікавленості, обізнаності й інтерактивності публіки в опері: композитори творять власні артефакти, в яких ключовим словом надалі виступає опера, але в значенні за межами жанрового канону; реакція слухачів/глядачів розмежована: від захоплення і здивування до роздратування. У такій ситуації в умовах появи Gesamtkunstwerk нової формації кооперація науковців і митців необхідна. Оцінка наслідків деструкції жанру опери, аналіз результатів опери як семіотичного об’єкта в його новій якості - спільна справа, актуальність якої

${ }^{2}$ Парин А. Прощание с Оперой Ивановной. Журнал ТЕАТР. 2012. № 6-7. URL: http://oteatre.info/proshchanie-s-operoj-ivanovnoj/

${ }^{3}$ Іваницька Я. Оперна вистава Як семіотичний об'єкт : дис. ... канд. наук : 17.00.03 «Музичне мистецтво». Національна музична академія України ім. П.І. Чайковського, Київ, 2008.

${ }^{4}$ там само.

5 Там само.

6 Там само.

${ }^{7}$ Lehmann, Harry. Die Kunst der reflexiven Moderne / Orientierungen: Wege im Pluralismus in der Gegenwartsmusik. Die Veröffentlichungen des Instituts der Neue Musik und Musikerziehung Darmstadt: Schott Band 47. S. 24-44. 
доведена на практиці. Про конкретні зразки і роль вокалістів у нових артефактах мова піде пізніше.

Музикознавці ще не виробили відповідної методики аналізу подібних артефактів, тому дискусії навколо задумів, концепцій, техніки і взагалі суті квазіоперних проєктів із синтезом оперного вокалу з етноспівом або репом, симфонічної партитури з електро-, рок-, технозасобами) поки що курсують на поверхні. Тим часом нові експерименти, присвоюють собі код «опера», маніфестуючи при цьому руйнацію онтологічних i аксіологічних критеріїв класичного оперного жанру.

Початковою метою і перспективним завданням цих розвідок є:

- здійснення огляду вибраних, найбільш рельєфних нині оперних артефактів сучасних композиторів;

- означення векторів взаємодії синтетичних музично-театральновізуально-медіальних засобів з оперою або артефактами, які іменують себе операми з інерції або з негоції;

- з'ясування перспективи оперних вокалістів у нових квазіоперних експериментах.

Очевидно, що дослідження нових опер i квазіопер із погляду соціологічного, комунікативного, медійного, навіть політичного результатів творчості випереджають оцінку мистецької значущості твору, адже остання потрібує випробування часом. Проте вектор вивчення оперної творчості українських композиторів у системі європейського антропосоціокультурного топосу пропонується в музикознавстві вперше.

Симптоматично, що під егідою оперної постановки в оперній практиці давно задіяний широкий спектр контекстних поляризацій, відомий на прикладах інтернаціональних антирасистських або екологічних проєктів Пітера Селларса, провокативних викликів політично-релігійному альянсу і державно-релігійній монополії Ганса Ноєнфельса. А постановки Грема Віка позиціонують оперу як унікальний об’єкт тотальної культурно-історичної комунікації.

\section{Розділ 1}

Театр завжди швидко реагував на історичні події і суспільні настрої, презентував на сцені актуальні проблеми, конфлікти і дискусії. Музично-сценічні інновації завжди є невід'ємним супутником опери, в якій співіснують міф і реальність, минуле і сьогодення, композитори i виконавці. Інтерпретатори світового оперного тезаурусу (диригенти, режисери, співаки) доводять на практиці, що оперні тексти кодують актуальні меседжі, випереджують (і попереджують) сучасність, а також окреслюють перспективи майбутнього. 
В останні роки позиція молодих авторів опер активізувалася. Як відомо, в оперних постановках XX-XXI століття суттєві зрушення торкнулися координації головних ролей. Хто займає пріоритетні позиції під час роботи над новою продукцією - режисер-постановник, диригент, художник-сценограф, дизайнер світла і костюмів чи оперні співаки? З'являються артефакти, в яких навіть лідерство композитора оспорюється або самоліквідується. Автори опер вже не є одноосібними деміургами, а диригенти і оперні вокалісти інколи навіть вважаються зайвими. Натомість акцент на колективній творчості, максимальна партиципація реципієнтів нагадують ритуальні витоки європейського театру, частково dramma per musica, що відроджувала уявлення про орфічні, діонісійські та інші містерії. У продукціях сучасних оперних проєктів задіяний великий творчий колектив: композитори, режисери, сценографи, драматурги, художники, хореографи, дизайнери, модельєри, кінооператори, інженери-оптики, майстри інтерактивних інсталяцій, 3D-маппінг тощо.

Для оперних співаків у такій ситуації орієнтири та координація вокальних і сценічних завдань розширюється, часом розпорошується, адже у великій творчій групі не кожен учасник процесу має фахові знання i уявлення про суть, місію i техніку оперного вокалу. У минулому оперні віртуози, осяяні славою primadonna і primoиото (musico), хоч і спровокували занепад барокової опери, проте на віки санкціонували статус першості вокаліста в опері. У сучасних оперних постановках співаки приймають виклик радикальних режисерів i усвідомлюють свою роль як secondo artista або «сам собі режисер». Акторські вимоги до співаків поряд із новою технікою інтонування виникли не сьогодні. Вікова оперна практика з шенберзько-бергівським Sprechstimme зазнала суттєвих інновацій і успішно розвивається в операх XX-XXI століття від Лігеті до Нойвірт. Але нарочита ротація оперного вокалу в бік не-оперного невідступно виборює свої права на «священній території» оперного мистецтва. Як симптом х-часу «постпост-модерну» опера перестала розумітися як жанр i в нових артефактах заявляє себе як поштовх, привід, код, символ або цитата.

Цікаво аналізувати поширені сентенції про смерть опери або тінь опери від сучасних митців i музичних критиків. 3 позиції феноменологічної соціології перформативні практики, що норовлять «відмінити» оперу (інколи при цьому навіть заперечують власний продукт творчості), виявляють пієтет до оперної історії, іiї творців і іiі героїв. Слушна думка про залучення слова опера як інструмента для підвищення значущості цілісного наративного виступу: «Не так важливо, чи відповідає це тому, що називається оперою у класичній 
музиці» ${ }^{8}$. Проте так звана «оперність» нових проєктів, які не потребують оперного вокалу і оркестру, обмежуються аудіоальбамами, онлайн-презентаціями, перформансами, сценічною реалізацією у вигляді відео-, кіно- або аудіоформатів загалом уявна. Наприклад, молода музикознавиця Ліза Сіренко слушно оцінила дилему квазіопер американського репера, співака, продюсера звукозаписів та модельєра Каньє Веста (відомого під арт-іменем Үе або Yеezy) так: «Не тільки як жанр, але і як форма опера створила лише правила гри, в котру можна бавитися класикам, рокерам, хіп-хоп-артистам, реперам та іншим музикантам. Тобто залишити усі атрибути опери і змінити стилістику наче просте оновлення, але, вочевидь, для некласичних артистів залучення формату опери означало інше - надати вагомості своїй lowart творчості $<\ldots>$, музика та сенси якої тьмяніють від світіння німбу high-art класичного мистецтва. Тому відповідь на питання «навіщо опера некласикам?» проста: позначити цілісність і завершеність (opus'ність) та наративність виступу чи музичного альбому, так би мовити «серйозність своїх намірів» ${ }^{9}$ (позн. - A.С.).

Оригінальним екземпляром low-art творчості, але 3 оперним вокалом (ім'я Марії Каллас зобов'язує!) став проєкт всесвітньовідомої перформансистки Марини Абрамович "7 Deaths of Maria Callas” («Сім смертей Марії Каллас»). На замовлення провідного європейського оперного театру Марина Абрамович зіграла, а точніше, втілила Марію Каллас у власній опері-перформансі «Сім смертей Марії Каллас». Не стільки сама Каллас-Абрамович, скільки опера $i$ перформанс символічно конфронтували, переживали еротичний акт єднання $\mathrm{i}$ вмирали на сцені Баварської Staatsoper. Життєтворче нутро «радикальної перформансисики, що пережила різні стадії ненависті до опери i, до речі, зізнавалася в цій своїй ненависті майже в кожному інтерв'ю, раптом вирішила відкрити світові свій давній (із 14 років) прихований сердечний зв'язок 3 оперою» ${ }^{10}$. Марина Абрамович перформансистка від плоті і крові - маніфестувала у "7 Deaths of Maria Callas" суто оперний феномен - сценічний культ тривалої пафосної смерті як гарантії безсмертя. Мисткиня в ролі оперної Діви інсценувала власну смерть під музику семи хіт-арій із репертуару Каллас і кінокліпів alla Hollywood від трилера до фентезі.

Заради справедливості зауважу, що в такий спосіб митці перформансу адресують свої маніфести на кшталт пафосу оперної

${ }^{8}$ Sirenko L. «Опери» кандидата в президенти США Каньє Веста. The Claquers. URL: https://theclaquers.com/posts/3851

9 Там само.

10 Єфіменко А. Музичні рейтинги IV «Збруч». 31.12.2020. URL: https://zbruc.eu/node/102505 
смерті або смерті опери не стільки репертуарним канонам жанру, скільки музейно-реставраційним або модерно-репрезентаційним продукціям сучасних оперних театрів. Жанр опери як неактуальний спочатку проголосили режисери, але їх спроби «реанімувати вмираючого» вдалися на славу. Надалі справою негоції режсисерської опери зайнялися молоді композитори. Їх можна зрозуміти: рецепція оперних артефактів як культурної традиції переважає над промоцією i виконанням сучасних опер, які змушені «існувати» «тут і зараз», але витіснені з оперних театрів в інші локації.

Тим часом молоді композитори апробують альтернативні можливості актуального Gesamtkunstwerk. Український митець Ілля Разумейко зауважив: «Не може сучасний композитор написати партитуру, музику i віддати це якомусь «дяді», який поставить сучасний перформанс або художнику, який щось намалює. Реально всі найбільш цікаві проєкти XX сторіччя - це Gesamtkunstwerk. Це і Тронд Райнхольдтсен, i Манос Цангаріс, і Маурісіо Кагель, і Штокгаузен. Саме такі проєкти дають змогу створювати щось нове і виходити на інший рівень. Бо інакше, якщо в композитора $є$ просто задача написати партитуру і здати іii, що вийде в кінці - дуже важко спрогнозувати, i дуже часто це не спрацьовує» ${ }^{11}$.

У відповідь на теоретизовані прогнози смерті опери в театральній практиці відбувається справжній оперний бум. Натомість нові артефакти сигналізують закон гегелівської діалектики в дії: заперечення заперечення у проєкції на смерть смерті опери. Нові квазіопери почали рости як гриби в лісі після парадоксального вивільнення опери від жанрових канонів. Суть нового феномена оперного проєкту в сенсі заперечення заперечення - справді інноваційна. Але звідки з'явилася мода називати оперою перформанси, аудіоальбоми, відеокліпи? Виявляється, така ідея росте 3 давнього коріння - етимології слова орега (з італійської - дія, праия, твір). У первинному сенсі opera або opus стикується з архаїчними поняттями про музичний твір як продукт колективної творчості, що був відновлений у XIX столітті в міфотворчості Ріхарда Вагнера. Прототипом вагнерівської утопії «Твору мистецтва майбутнього» (вжене-опери) i була колективна творчість середньовічних цехових майстрів. Gesamtkunstwerk (Gesamt-Kunst-Werk - сукупний мистецький твір), відтворений у «Нюрнберзьких майстерзінтерах», являв на сцені повсякденну життєву реальність Gesamt-Künstler-

\footnotetext{
${ }^{11}$ Sirenko L. Де шукати сучасну оперу? \#9: Роман Григорів, Ілля Разумейко Nova opera та «Чорнобильдорф». The Claquers. 17.9.2020. URL: https://theclaquers.com/posts/4437
} 
Werkstatt (сукупна праця майстрів). Проте з позиції феноменологічної соціології парадокс Вагнер-Міфа став взірцем життєтворчості (життєсвіту) не колективу, а єдиного Майстра, неповторного i безпрецедентного в усій театрально-музичній історії.

\section{Розділ 2}

У сучасному світі «Opera як процес» статус Майстра і Автора мультиплікується. Кооперація багатьох авторів, вже не анонімних, як у часи середньовіччя, а іменитих, бажано «зірок», пролонгованих маркетинговими агенціями (відповідно до оціночних критеріїв їхньої професійної елонгащіï), заздалегідь передбачена продюсерами постановок. Проте від цього стирається суть місії оперної «зірки» в оперi, котра зрівнялася зі «зірковими» іменами митців зі суміжних видів мистецтв (художниками, дизайнерами, модельєрами тощо). Хоча людський голос, як був, так i залишився важливим i, напевно, найщирішим інструментом оперної матерії, за Є. Новак ${ }^{12}$, голосом-тілом, чутливим до емоційних і фізіологічних станів, до умов творчості, атмосфери в колективі. Але в нових операх (opera в сенсі дія, праия, твір) вимоги до вокалу кардинально помінялися. Дихотомія голос-тіло орієнтована на реактивні, природно-фізіологічні навички вокаліста. Фокус сценічних експериментів режисерів-постановників у барококласико-романтичному репертуарі, а також модерно-постмодерних операх не зациклюється на віртуозності вокалістів. Пріоритетним виступає не естетично-емоційний вплив вокалу на авдиторію, а артистизм співака. Голос почав усвідомлюватися як «досвід реляції (відношення, зв'язку) між творцями і реципіснтами $<\ldots>$ через реальну включеність публіки у дію.., створення ситуації присутності й спільної вібрації» ${ }^{13}$. Що це означає в сучасній оперній практиці? Деякі режисери зробили собі ім'я завдяки оперним проєктам на межі опери і реаліті-шоу. Так, режисер Грем Вік (керівник Бірмінгемської опери) в постановках апелює до феномену дієвого впливу музики на людину і дає змогу глядачам-добровольцям безпосередню взяти участь у виставі ${ }^{14}$. Як зауважив режисер, мета його постановок - не віддати опері належне,

${ }^{12}$ Novak J. Postopera: Reinventing the Voice-Body. 2015. Routledge-Verlag. $192 \mathrm{~S}$. ISBN: 978-1-4724-4103-4; Operofilia 2018. Belgrade: Orion Art. 182 p. ISBN: 8663890885; Einstein on the Beach: Opera beyond Drama (co-edited with John Richardson). 2019. Routledge-Verlag. 350 p. ISBN 9781472473707

${ }^{13}$ Risi C. Die Stimme in der Oper zwischen Mittel des Ausdrucks und leiblicher Affizierung / Die Zukunft der Oper. Zwischen Hermeneutik und Performativität. Herausgegeben von Barbara Beyer, Susanne Kogler und Roman Lemberg. Berlin: Theater der Zeit. Recherchen 113. S. 272-273. ISBN 978-3-943881-88-2. S.267-275.

${ }^{14}$ Vick, G. Atme das Leben. URL: http://operavision.eu/de/bibliothek/auffuehrungen/ opern/fidelio-birmingham-opera-company\#einblicke 
скажімо, повагу, захоплення, пієтет, а повернути втрачене ${ }^{15}$, тобто іï первозданну функцію суспільної комунікації. Зібрання громади в партиципальному акті Вік вважає необхідним базисом будь-якої колективної праці, зокрема опери. Мета такої постановки - єднання публіки і музикантів. А завдання вокалістів балансує на межі emotio i actio - зворушити-зрушити, вплинути-залучити i, головне, спонукати публіку робити оперу разом. Отже, в таких постановках опера усвідомлюється як чинник людської діяльності в історії, культурі та стає сучасним соціологічним експериментом. Притаманний опері онтологічний синкретизм дає змогу на стиках різних фрагментів іiі сукупної «генетики» (семантичного, жанрово-стильового інваріантів) творити нову преформацію. Антропо-соціо-культуро-логічний сенс рецепції таких оперних постановок дає змогу не лише побачити крізь призму мистецтва етапи розвитку людини - homo creator, типів мистецької діяльності, самоідентифікації індивідуума в суспільстві, а стати самому учасником цих процесів. Сенс оперної творчості композиторів, режисерів, диригентів, співаків - комунікація, вміння висловитися «виразною художньою мовою відкрито і відверто про те, який нині світ, як в ньому жити і чи є шанс жити гідно» ${ }^{16}$.

Як свідчать нові оперні проєкти українських авторів, саме ці фактори (антропологічний, психофізіологічний) означили потребу в новому muni вокаліста. Співакам варто ознайомитися 3 дослідженням феномена голосу-тіла Єлени Новак ${ }^{17}$, зокрема, 3 працями «Постопера: перевинайдення голосу-тіла» (2015), «Оперофілія» (2018), «Ейнштейн на пляжі: Опера за драмою» (у співавторстві з Джоном Річардсоном, 2019). Суть голосу-тіла як продукту смислу розбирається в парадоксальних інноваціях сучасних квазіопер зі «співом поза людьми». Ко-режисер i драматург Сергіо Морабіто ${ }^{18}$ зазначає в оперних проєктах або проєктах «про оперу» дифузію голосу як складник дифузії фоми non-finita. Незавершеність, нескінченність процесу work-in-progress запрограмовані митцями, котрі вільно поєднують оперні фрагменти, перформанс, віртуальну гру, кіно, шоу і багато інших фантазій і сюрпризів. Зерно

${ }^{15}$ Vick, G. Там само.

${ }^{16}$ Парин А. Прощание с Оперой Ивановной. Журнал ТЕАТР. 2012. № 6-7. URL: http://oteatre.info/proshchanie-s-operoj-ivanovnoj/

${ }^{17}$ Novak J. Postopera: Reinventing the Voice-Body. 2015. Routledge-Verlag. $192 \mathrm{~S}$. ISBN: 978-1-4724-4103-4; Operofilia 2018. Belgrade: Orion Art. 182 p. ISBN: 8663890885; Einstein on the Beach: Opera beyond Drama (co-edited with John Richardson). 2019. Routledge-Verlag. 350 p. ISBN 9781472473707

${ }^{18}$ Morabito, Sergio: „die tollkühne Tour de force einer spielerischen Dynamisierung der fixierten Partitur (über Dramaturgie im Musiktheater). Regie für ein Haus. Vortrag für Auftakt! Der Oper Stuttgart am 17.9.2017. URL: https://www.yumpu.com/de/document/ $\mathrm{read} / 21636705 / 1$-regie-fur-ein-haus-vortrag-von-sergio-oper-stuttgart 
термінологічної дуальності opera aperta, заповіданої Умберто Еко, почало давати цікаві оперні плоди.

Сучасний світ опери потребує активної кооперації оперних театрів, зайнятих процесами оновлення репертуарного тезаурусу не лише 3 режисерами, a i з молодими композиторами. Чи мають рацію композитори-сучасники, які звинувачують у смерті опери режисерів (I. Разумейко: «Режисерська опера - ие смерть» $\left.{ }^{19}\right)$ ? Категоричність у цьому питанні навряд чи виправдана. Досвід «режисерської опери» свідчить про те, що, коли постановники втрутилися в «музей» опери «з новими ідеями, почерпнутими в драматичному театрі, образотворчому мистецтві, кіно, танці - опера народилася наново ${ }^{20}$. А вокалісти, відповідно, розширили свою вокальну кваліфікацію і стали яскравими акторами. Проте на тлі розквіту західноєвропейської режисерської опери або «музейної» монополії українських оперних театрів цілком виправдані прагнення молодих композиторів знайти власну нішу для творчості і сучасного Gesamtkunstwerk.

Головною причиною рефлексій на теми смерті опери між композиторами, диригентами $\mathrm{i}$ режисерами були, як правило, непорозуміння або неузгодженість музичного і театрального концептів. Достатньо згадати перипетії навколо постановки опери «Південний полюс» (,South Pole“) молодого чеського композитора Мирослава Срнка, прем'єра якої відбулася в Баварській Staatsoper 31 січня 2016 року. Після ознайомлення 3 концепцією режисера і макетом сценографії композитор переробив третину партитури. Візуальне очікування композитора щодо сценічної імітації Антарктиди як «реального місця на планеті», нескінченної снігової рівнини виявилося непридатним для режисерасюрреаліста Ганса Нойєнфельса. Музика була вже створена, але режисер переконував композитора новою візією Антарктиди як сюрреалістичною імітацією психологічного стану протагоністів. I, як пізніше зауважив Мирослав Срнка, режисерська концепція Ноєнфельса «потребувала особливої сценічної стилізації» ${ }^{21}$, 3 якою мала резонувати музика. Для композитора редакція музичного тексту, адаптація під режисерську ідею стала компромісом, не погодитися на який дорівнювало би зриву постановки. Але клаустрофобічно замкнена мертво-біла сюрреалістична сценографія з чорним хрестом на стелі ідеально резонувала зі «звучанням

\footnotetext{
${ }^{19}$ Sirenko, Liza. Де шукати сучасну оперу? \#9: Роман Григорів, Ілля Разумейко | Nova opera та «Чорнобильдорф». The Claquers. 17.9.2020. URL: https://theclaquers.com/posts/4437

${ }^{20}$ Парин Алексей. Прощание с Оперой Ивановной. Журнал ТЕАТР. 2012. № 6-7. ISBN 0131-6885.

${ }^{21}$ Подорож до Антарктиди. Euronews. 04.02.2016. URL: https://ua.euronews.com/2016/02/04/journey-to-the-antarctic
} 
безкрайнього снігового простору». Мирослав Срнка досягнув $\mathrm{i}$ клаустрофобічної атмосфери сонористичними, спектральними засобами, а також уведенням у вокальні партії протагоністів імітацій азбуки Морзе, радіосигналів, частотних викривлень радіомузики, звукової «конкретики» тріску полярної криги тощо. Тандем Срнка-Нойєнфельс став виграшним i успішним для обох митців, хоча цей приклад - лише один із доказів відомого факту: маститі режисери диктують умови і адаптації музики не завжди можуть виявитися вдалим компромісом. Наприклад, якщо постановники черпають свої ідеї, контексти і контрапункти не з музики, а 3 інших джерел власного мистецького досвіду, «режисерська опера» теж може виявитися приреченою на смерть. I, врешті-решт, композитори пишуть музику не для режисерів.

Для кого написані нові опери, питання риторичне i потребує відповідної реакції як від митців, так і від публіки. Згадаймо чудовий вислів колишнього директора Гамбурзької галереї мистецтв Густава Паулі: «Музей - це витвір сучасного соціального способу мислення» ${ }^{22}$. Слово музей замінимо на слово опера і отримаємо суть і квінтесенцію змін сучасної композиторської оперної практики. Для вокалістів робота над сучасною партитурою відкриває не лише нові техніки, а й нові виклики. Роландо Вільязон (виконавець партії Роберта Скотта в опері „South Pole“) зауважив: «Я став дослідником у цьому новому світі, дослідником цих нових гармоній і нової музичної мови, до якої я не звик. I це було надзвичайно, просто дивовижно. Дуже гарно те, що чим більше працюєш над цим, тим більше воно проникає в тебе, у самий мозок, у тіло. I тим глибше можеш відчути цю музику» ${ }^{23}$. Сценічний конкурент Вільязона Томас Гемпсон (виконавець партії Руаля Амундсена) упевнено заявив: «Нові опери дуже важливі, <..> нам потрібно підтримувати композиторів і лібретистів. Їм необхідна можливість розвиватися й писати нову музику. Ми маємо створювати нові опери» ${ }^{24}$.

До переконливих сентенцій вокалістів на користь нових опер підключилися музикознавці. У відповідь на оперний театр-музей або свавілля режисерів медіа ставлять руба питання, скріпивши його знаком «решітки» ${ }^{25}$ «\#Де шукати сучасну оперу?» ${ }^{26}$ На часі не

${ }^{22}$ Матт Г., Флатц Т., Льодерер Ю. Культура і гроші. ВП «Юніверс» / переклад О. Кислюк. 2009. С. 7. ISBN 978-966-8118-71-5.

${ }_{23}^{23}$ Подорож до Антарктиди. Euronews. Там само.

${ }^{24}$ Там само.

${ }^{25}$ Свідомо заміняю нав'язаний онлайн-лексикою американізм «хештег» адекватним українським словом «решітка», пропоную заміняти всі американізми адекватним перекладом, щоб зберегти на майбутнє мелодійне звучання української мови.

${ }^{26}$ Sirenko L. The Claquers. Подкасти. URL: https://theclaquers.com/posts/category/ podcast 
теоретичні й історичні дослідження оперного жанру, а вивчення конкретних артефактів, які відображають «сучасний соціальний спосіб мислення» композиторів і співаків.

В оперних проєктах українських митців варто зауважити залучення не-оперного вокалу. Вокалісти і композитори тепер співтворці. В оперіміфі «Ukraine - Terra Incognita» з посвятою оперному співаку Василю Сліпаку (образ «новітнього Мамая») авторкою ідеї, ініціаторкою проєкту, режисеркою і співачкою стала дослідниця архаїчного співу Уляна Горбачевська. Для реалізації оперного проєкту мисткиня шукала однодумців - композитора, що вміє працювати з архаїчним музичним матеріалом, i солістів 3 «акторськими здібностями i життєвою позицією» ${ }^{27}$. «Ukraine - Terra Incognita» позиціонувалася як українська альтернатива світовій оперній традиції. В якості української опери представлений перформанс колективного виконавця-творця архаїчного голосу-тіла, що відтворює у співі і хореографії магію старовинних обрядів, рудиментарні форми ритуальних співів і танців із залученням відеоарту, квесту, оригінальних костюмів, театральної імпровізації тощо. Усі співаки «Ukraine - Terra Incognita» - як майстри техніки архаїчного співу, так і перформери. Обрядово-перформативна мода на етнопроєкти перспективна, поки не переходить на рівень псевдоетнографічної декоративності. А щодо мутацій голосу-тіла в українській опері, то цей шлях ініційований ідеєю «запатентувати» власну національну традицію вокалу праоперної ери. Задум оригінальний, проте ставити в один рівень перформанси, що демонструють сучасні метаморфози архаїчного співу зі західноєвропейською оперною традицією, в якій невід'ємним голосомтілом є професійно вишколений артифіційний оперний вокал і також, 3 огляду на дискретність оперної традиції в Україні, здається поки що нерівноцінним викликом. Хоча музикознавці рекомендують використовувати фольклор як природну лабораторію музичного мислення (В. Москаленко). Чому би не скористатися архаїчною інтерпретацією голосу-тіла як одного 3 елементів сучасної опери? Наприклад, у «Чернобильдорфі» архаїчний спів логічно сприймається чинником Gesamtkunstwerk і дуже вдало передає процес творення ідеї archaeological opera як «археології музичного мислення» постапокаліптичного суспільства. Композитори у форматі opera aperta конструюють «культурний постапокаліпсис». Як зауважив композитор Ілля Разумейко, «постапокаліпсис у фільмах дуже однобоко показаний:

\footnotetext{
${ }^{27}$ Терещук Г. Опера-міф «Ukraine - Terra Incognita»: Paдiо Свобода. 10 серпня 2020, 12:37. URL: https://www.radiosvoboda.org/a/ukraine-terraincognita/30775399.html
} 
люди шукають консерви, щоб вижити і втікають від зомбі. Нам цікаво зробити постапокаліпсис, в якому будуть фрагменти алгоритмічної музики, залишки пісень Шуберта, фрагменти фольклору» ${ }^{28}$.

Отже, opera aperta корелюється 3 forma aperta, conceptum apertum, fine aperto для слухачів - reflexio aperto, для співаків - vox aperta. У мультимедіальному просторі постановки задіяні не оперні вокалісти, а носії автентичної манери співу Сусанна Карпенко і Олексій Заєць зі села Красно (10-кілометрова зона Чернобиля). Дуже доречною видається в цьому зв'язку і сентенція культового українського поета Юрія Іздрика, який зіграв у «Чернобильдорфі» роль Орфея-поета: «У наші дні насправді це i є часи Апокаліпсису - така тематика і такий погляд на культуру не стільки археологічний, як антропологічний ${ }^{29}$. Отже, археологічні знахідки митців постапокаліпсу творять «місток» часів до і після і з віднайдених артефактів як у справжніх фентезі («творча візія майбутнього постапокаліпсису») ловлять сигнали vox humana. Ритуальний, культурологічний, антропологічний сюрреалізм на сцені «Чернобильдорфу» - лише зовнішній шар унікального твору, котрий на місті проголошеної постопери творить «абсолютно нову мистецьку стихію» - значно глибшу стихію, як оперний проєкт зі стильовим гаслом «тотального еклектицизму» ${ }^{30}$. До кола різнорідних складників opera aperta (forma aperta, conceptum apertum, reflexio aperto, vox aperta органічно підключається style aperta на місце колишньої полістилістики. У серії інтерв'ю з митцями можна почерпнути багато цікавої інформації про реалізацію мегазадумів на кшталт творення міфо-світу, що «перебуває в постійній трансформації» ${ }^{31}$. Симптоматично, що автори опери «Чернобильдорф» усвідомлюють себе правнуками Ріхарда Вагнера, онуками Голлівуду i дітьми Штокгаузена: «У плані мегаломанських проєктів у нас є пра-прадідусь, це Ріхард Вагнер, зауважує Ілля Разумейко. - I навіть у грантовій заявці УКФ ми вписували слово Gesamtkunstwerk, тож працювати справді цікаво. Вагнер - один із родоначальників цього мегаломанства, його навіть вважають одним із родоначальників сучасного Голлівуду. Наступний мегаломан,

\footnotetext{
${ }^{28}$ Sirenko L. Де шукати сучасну оперу? \#9: Роман Григорів, Ілля Разумейко Nova opera та «Чорнобильдорф». The Claquers. 17.9.2020. URL: https://theclaquers.com/posts/4437

${ }^{29}$ Карпенко Л. «Чернобильдорф» - археологія майбутнього. Українська правда. Життя. 2020. 3 грудня. URL: https://life.pravda.com.ua/columns/2020/12/3/243254/

${ }^{30}$ Мигашко О. Ілля Разумейко та Роман Григорів про Chornobyldorf: «Ми займаємось мистецькою некрофілією». Yabl. URL: https://yabl.ua/2020/11/07/illya-razumejko-ta-roman-grigoriv-pro-chornobyldorf-mizajmayemos-misteckoyu-nekrofiliyeyu

31 Там само.
} 
продовжувач Вагнера, - це Штокгаузен» ${ }^{32}$. Іллю Разумейка і Романа Григоріва можна сміливо називати i онуками Едмунда Гуссерля. Феноменологія почалася 3 тези Гуссерля «Назад, до самих речей!» Композитори постулюють «Назад, до самих артефактів!» - очевидність «всеосяжної єдності сущого» i візія пережитого досвіду. «Чернобильдорф» якості opera aperta розвивається у форматі гри з часом (Рея - богиня часу i, водночас, інструмент часу - Rhea-player алгоритмічне фортепіано австрійця Вінфріда Рітча) ${ }^{33}$. Вокаліст, його голос, його театральна самопрезентація символізують не відновлення пам'яті опери, а очікування, пошук і відновлення комунікації, в якій феноменологія сприйняття часу (в цьому випадку - часу вистави) циклічна - як у міфі, як у давніх греків, як у всіх до-апокаліптичних цивілізаціях. Аналізуючи феномен «цитатності» ${ }^{34}$ в цій опері 3 позиції співвідношення оперної пам'яті (Retention) і очікування (Protention), а також з огляду на перцептивну ситуацію оперного голосу вокаліста в пригоді стає трактування терміна Гуссерля Retention. Суть нашого слухового сприйняття фрагментів пам'яті (Retention) служить провайдером звукового конструювання майбутнього на уламках минулого (Protention) ${ }^{35}$. Як вдало зазначила молода музикознавиця Анастасія Сисенко: «Люди постапокаліптичної генерації досліджуватимуть віднайдені в пустелях артефакти, творитимуть міфи, відтворюватимуть звучання, музичні фрагменти, залишені на золотих платах. I вони прислухатимуться один до одного в спільному музикуванні, поки різні імперативи і рефлексії сформуються в гроулінгу

32 Там само.

33 Детальніше про спроектовану систему з використанням плат, яка примушує фортепіано звучати без музиканта, про завантажену програму музичного твору, що керується з комп'ютера за допомогою програм PD та Max MSP див. у: Карпенко Л. «Чернобильдорф» - археологія майбутнього. Украӥнська правда. Життя. 3 грудня 2020. URL: https://life.pravda.com.ua/columns/2020/12/3/243254/

${ }^{34}$ Поряд 3 автентичним співом в опері використовуються мікротональні варіанти української пісні «Сонце низенько» 3 опери «Наталка Полтавка» М. Лисенка, парадоксальне злиття літургійного тексту (Agnus Dei з Меси Й. С. Баха) і мелодії української народної пісні «Летіла стріла», прелюдія fis-moll Й. С. Баха (1-й том ДТК), хор з кантати Weinen, Klagen, Sorgen, Zagen, хоральна Прелюдія Й. С. Баха на лютеранську тему Ich ruf zu dir, Herr Jesu Christ, популярна дитяча пісенька «Брат Якоб» або «Брат Жак», яку раніше Г. Малер перетворив на «Жалобний марш в манері Калло» (Симфонія № 1 Г. Малера, III частина), потім Григорів-Разумейко - на поховальний ритуал разом 3 артефактом преапокаліптичним артефактом - голови «золотого Тільця-Леніна», також елементи Hard-Rock, використання акордеону в стилі конкретної музики тощо.

${ }^{35}$ Husserl, E. Husserliana. Gesammte Werke, Bd 10. Zur Phänomenologie des innerem Zeitbewusstsein (1893-1917). S. 19-72. 
або співі» ${ }^{36}$ (курсів - A. $C$. ). Музичний матеріал опери «Чорнобильдорф» ставить особливі вимоги і випробування як для інструменталістів, так i для вокалістів. Самі композитори (тандем Григорів/Разумейко) співають i музикують поряд зі своїми протагоністами, самі $\epsilon$ активними протагоністами власної опери, повертаючись до ренесансного ідеалу універсальних митців. Опановуючи музичні скарби загиблої цивілізації, вони грають то на цимбалах і мікротональній бандурі, то на альпійській цитрі, кантеле, морін хуур (монгольська народна двострунна віолончель), творять наново враження неповторності живої імпровізації. При цьому композитори не керують, а партиципують ситуацію колективного музикування як вроджений дар, притаманний людській природі. Уявно кожен може взяти участь у такому процесі оперотворення і творити свою opera aperta.

Однак проблематика opera aperta не розв'язує, а навпаки, загострює дискусії навколо суті оперного вокалу в нових форматах постопери, анти- або анти-анти-опери, мініопери та інших. Рок-опери, що давно зайшли на територію класично-романтичної оперної традиції ${ }^{37}$, заперечили енергетичний потенціал тренованого оперного голосу i субординацію елітарної і масової культур, що й породило «кілерів» музейної опери i «пророків» opera aperta. Зміни преференцій iз тренованого голосу-тіла оперних співаків на реп-, рок-, етноспів, семіотичні модуляції оперного тексту, зміни жанрових парадигм на бліц-проєктні, медіаартові окреслюють одну з тенденцій мистецького синтезу. На уламках Gesamtkunstwerk розгортається нова інтрига: синтез оперної деструкції з антидеструкцією. Спостерігати за цими процесами дуже цікаво, але передбачити «модуляції» закону заперечення-заперечення: «перформанс-мінус-опера чи опера-плюсперформанс у синтезі аудіо-, відео- і візіоартами, дизайном моди, галерею живопису - поки що неможливо ${ }^{38}$. Солістка Віденської опери українська мецо-сопрано Зоряна Кушплер, як і інші молоді сучасні вокалісти, впевнена, що сучасна опера житиме дедалі більше в аурі перформенсу $^{39}$ i, очевидно, в аурі «зірок» у всьому різнобарв 'ї ї профорієнтації. Процес залучення іменитих митців - видатних

${ }^{36}$ Сисенко А. Чорнобильдорф - постапокаліптичні пошуки опери. Музика. 27 січня 2021. URL: http://mus.art.co.ua/chornobyldorf-postapokaliptychni-poshuky-opery/

${ }^{37}$ Sirenko L. «Опери» кандидата в президенти США Каньє Веста. The Claquers. URL: https://theclaquers.com/posts/3851

${ }^{38}$ Єфіменко А. Музичні рейтинги IV «Збруч». 31 січня 2021 року. URL: https://zbruc.eu/node/102505

${ }^{39}$ Кушплер 3. Сучасна опера живе в аурі перформенсу. Збруч. 2020. 2 вересня. URL: https://zbruc.eu/node/100030 
живописців, дизайнерів моди, світла, інтер'єру - показує поки що захопливі результати.

Творчий альянс композиторів із видатними літераторами, художниками, дизайнерами свого часу історично зумовлений. Сам Ріхард Вагнер мріяв співпрацювати з Арнольдом Бьокліним, готуючись до прем’єри «Валькірії» ${ }^{40}$. Плідним був і мистецький альянс дягілевських «Російських сезонів у Парижі» 3 художниками-міріскусніками. Львівська національна опера імені Соломії Крушельницької пишається унікальною колекцією декорацій Євгена Лисика, що входять до Золотого фонду театру. У 2020 році з нагоди 90-річчя 3 дня народження Свгена Лисика (1930-1991) - художника-сценографа, співавтора 76 вистав у театрах України, Росії, Білорусії, Польщі - була відновлена постановка балету «Створення світу» Андрія Петрова.

Поряд зі «зірками» оперного вокалу давно увійшло в моду запрошувати до оперних постановок «легенд» сучасного живопису Йорга Іммендорфа («Ніс», «Електра»), Георга Базеліца («Парсіфаль»), Нео Рауха («Лоенгрін»), Вільяма Кентріджа («Лулу», «Воццек»), навіть таких митців-інсталяторів, як прославлений дизайнер світло-дзеркал Олафур Еліасон («Федра» Г. В. Генце, «Іпполіт і Арісія» Ж.Ф. Рамо). Цікаве трактування ролі вокалістів у вигляді суб'єктів з уламків дзеркал, що рефлектують лазери світла, - лише один 3 прикладів мистецького діалогу Еліасон-Рамо. Не секрет, що видатні митці трактують вокалістів як персонажів власних картин, інсталяцій, перформансів. Співаки характеризують такий метаоперний досвід співпраці 3 художниками приблизно в одному ключі. Реакція шведської сопрано Ніни Стемме, яка співала в «Парсіфалі» 3 картинами Георга Базеліца, у «Царі Кандавла» фон Цемлінського з декораціями Альфреда Хрдлічки, в «Турандот» із поп-арт-сценографією Девіда Гокні (2010 рік, Сан-Франциско) була такою: «Ми - елементи твору сценічного мистецтва» ${ }^{41}$. Незважаючи на той факт, що естетичні мови Базеліца і Гокні далекі одна від одної, результати схожі. В обох випадках - це сценічні полотна, що приголомшують уяву. А виконавці здебільшого грають у таких виставах фігуративну роль, будучи одним 3 елементів великого живописного полотна художника. Як розповідає Ніна Стемме, «в інтерпретації Гокні у

\footnotetext{
${ }^{40}$ Вагнерівську мрію частково здійснив Патріс Шеро - патріарх режисерської опери, знаменитий французький режисер, проголошений у 1976 році автором «Перстня століття» (Jahrhundertring). Режисер відгукнувся на мрії Вагнера i запросив відомого французького художника і архітектора Рішара Педуцці, який очолює Академію мистецтв "Académie de France à Rome», оформити сценографію «Валькірії» за мотивами картини «Острів мертвих» А. Бекліна. Так і народилася знаменита беклінівська скеля Валькірії.

${ }^{41}$ Браун С. Из другой оперы: художник в роли постановщика. The Art Newspaper Russia. 18 сентября 2020. URL: http://www.theartnewspaper.ru/posts/8401/
} 
фінальній сцені «Турандот» Принцеса і Калаф закохані один в одного: ми беремося за руки, і наші мантії творять контур серця, а на узвишші над нами сидить імператор ${ }^{42}$. Такий досвід свідчить, що важливою складовою частиною успішної театральної колаборації композиторів і художників все одно залишається здатність митця рельєфно представити розвиток свого образа, від якісно до унікально озвучити партію, тобто стати голосом-тілом свого героя, незалежно від того, якими зовнішніми виразовими засобами ця мета буде досягнута.

Проте завдання інтендантів і театральних менеджерів - розширити ринковий попит на оперну продукцію. Загальновідомо, що екстраординарні вистави притягують люксову публіку, королев, принцес, графів, поп-зірок, якщо в оперних продукціях задіяні імениті модельєри. Практика кооперації оперних театрів із дизайнерами моди поширена i заслуговує на окреме дослідження. Але згадаємо, принаймні, найбільш знакові приклади. Легендарний режисер Роберт Віллсон у 1987 році створив «Саломею» для міланського Teatro alla Scala 3 костюмами «легенди» італійської моди - Джанні Версаче. Останній, до речі, зобов'язаний своїми дизайнерськими ідеями саме опері і балету. Саме Віллсон і Бежар вплинули на стиль Версаче. Як стверджував митець, завдяки Бежару він зрозумів рухи танцю і відтворив у своїх моделя ${ }^{43}$. Те саме стосується і робіт Жака Рейно - відомого італійського модельєра. Разом із Віллсоном він готував постановки «Турандот» (Мадрид), «Отелло» (Баден-Баден), «Коронація Поппеї» (Мілан) і «Мессія» (Зальцбург). Інша «зірка» світової моди - японський дизайнер Йоші Ямамото розробляв костюми для постановок «Трістан і Ізольда» (Байройт) i «Мадам Баттерфляй» (Ліон). Відома модельєрка принцеси Грейс, Ненсі Рейган, імператриці Мітіко Ханає Морі вдягала також героїв опер «Мадам Баттерфляй» і «Електра», балету «Попелюшка», мюзиклу «Евіта». Нарешті засновник італійського бренду Valentino Валентіно Гаравані - створив романтичні костюми для «Травіати» в постановці Софії Копполи для Римської опери.

А ось актуальні приклади. Японська дизайнерка Рей Кавакубо (Prêtà-porte, Modelabels Comme des Garçons) розробила фантастичні костюми для протагоністів опери Ольги Нойвірт «Орландо» у Відні. Композиторка потребувала для своєї hybride Grand Opera злиття моди, літератури, простору i відео 3 музикою. Улюблений модельєр королеви-консорт Нідерландів Максіми і Леді Гага - нідерландець Ян Таміняу - конструював сюрреалістичні костюми до опери «Рітратто»

${ }^{42}$ Браун С. Из другой оперы: художник в роли постановщика. The Art Newspaper Russia. 18 сентября 2020. URL: http://www.theartnewspaper.ru/posts/8401/

${ }^{43}$ Carrera, Martino. La Scala's Costumes Exhibition Bows in Milan. On October 16, 2017. WWD. Fashion. Beauty. Business. URL: https://wwd.com/fashion-news/fashionscoops/la-scala-costumes-exhibition-bows-milan-11028383/ 
голландського композитора Віллема Джетса. Британський модельєр Гарет Пью став автором авангардних костюмів Франко Фаджолі зіркового контр-тенора і головного протагоніста опери Франческо Каваллі «Еліогабало». Модельєр систематично співпрацює з оперними продукціями. Наприклад, у співпраці з художником Гошкою Макугою і лондонською фірмою Virtual Reality (Werkflow) Гарет Пью створив амбіційні костюми у стилі футуризму і поп-іконографії для героїв опери «Антигона» Томазо Траетта для Театру Касселя. Лстання прем'єра «Пеллеаса і Мелізанди» на сцені Grand Théâtre de Genève вразила інноваційними костюмами голландської дизайнерки високої моди Iріс ван Герпен, яка співпрацювала зі співачками Björk i Lady Gaga. У роботі з тканиною застосована оптична 3D-техніка. Химерне поєднання ефектів органіки - як скульптурної (скелі від Марини Абрамович у ролі сценографа), так і флористичної (сукня Мелізанди) створили вражаючий візуальний ефект ${ }^{44}$.

В українських операх, до прикладу, сюрреальна символіка «візуальної археології» костюмів української опери «Чернобильдорф»- оригінальний продукт співтворчості композиторів Романа Григоріва і Іллі Разумейка з дизайнеркою Катериною Маркуш. А помпезна розкіш костюмів до нової вистави Львівської національної опери «Турандот» завдячила відомій польській художниці Малгожаті Слоньовській.

Костюми видатних модельєрів - самостійні мистецькі об'єкти, витвори мистецтва високої моди, гідні прикрашати музеї, подіуми fashion show i арт-аукціони, на яких маклери вправі виставляти високі цінові старти для люксових клієнтів і оперних фанатів. Історія рецепції опери i дизайнерських мистецьких витворів - ознака контакту з улюбленими оперними зірками у векторі голос-тіло-костюм - все це разом виправдовує нові оперні бренди на кшталт Саломея-Кабальє-Версаче.

Отже, не лише режисери, а й художники, відеодизайнери і модельєри, причетні до переформатування опери 3 твору для слухачів на твір для глядачів. Звідси виникає низка запитань. Чому homo audiens витісняє homo videns? Чому сучасні оперні постановки між співом і модою, між мюзиклом і кіно надають перевагу перформансу, а не вокалу? Чи стануть такі дискусії вагомим аргументом смерті опери? Куди веде парадокс «співати в опері не актуально»? Яка перспектива деструкції барочнокласико-романтико-модерного жанру опери на користь розвитку фолк-, рок-, реп- проєктів і квазіопер, в яких превалює не-оперний вокал? Відповіді на деякі з цих запитань знаходимо в композиторів і вокалістівакторів. Якщо в постановках художників вокалісти готові бути

44 Єфіменко А. Музичні рейтинги IV. Збруч. 2021. 19 Січня. URL: https://zbruc.eu/node/102505 
інтегральною складовою частиною живописного полотна (а не навпаки, згідно з традиційним співвідношенням театральної дї̈ і декорацій), то можуть пристосуватися і до нових реалій пере-інтонування як наслідку пере-винайденого голосу-тіла. У творах молодих композиторів вокалісти виступають як рівноправні акустично-, технічно-, фонетично вибіркових експериментів звукоутворення. В умовах пост- або пост-пост-модернізму маніфести на кшталт смерті оперного вокалу (принагідно згадаймо і давню дискусію про смерть автора) не загрожують розвитку новітніх Gesamtkunstwerk, адже на місце одного вокаліста (одного автора) приходить інший, тільки субординація між ними змінюється.

Поки опера «Ніч» Максима Коломойця на лібрето Тараса Фролова ${ }^{45}$ експериментує 3 поєднанням розмовних діалогів, оперних і відкритих голосів, оркестрової технопартитури, археологічна опера «Чернобильдорф» ${ }^{46}$ та опера-міф «Ukraine - Terra Incognita» віддають перевагу архаїчному звукоутворенню. У подкастах онлайн-платформи The Claquers, присвяченої класичній музиці в Україні, серія бесід 3 авторами опер (серед українських композиторів - Алла Загайкевич, Олександр Щетинський, Золтан Алмаші, Роман Григорів, Ілля Разумейко, Андрій Мерхель, Юлія Філіпська, Олександр Чорний та ін.) прояснює причини мутацій оперного вокалу в медіа-арт-умовах. Вокал включається в нові резонансні умови сонористичного простору, звукову тканину електроакустичної музики, перформативні експерименти 3 альтернативним ставленням як до наративу, так і до інтонування. Наприклад, монооперу «Ентропія», створену за мотивами книги «Дім денний, дім нічний» нобелівської лауреатки Ольги Токарчук, Андрій Мерхель (співзасновник, мистецький керівник Sed Contra Ensemble) називає квазіоперою саме через відсутність наративу i традиційної оперної партитури. Натомість Алла Загайкевич доводить історичну суть

${ }^{45}$ Нова сюжетно-інтонаційна версія пісні «Ніч яка місячна», яка і стала «голосом-тілом» твору - як у партитурі, так і у концертному виконанні опери.

${ }^{46}$ Коротко суть опери про постапокаліптичні поселення нащадків людства на руїнах атомних станцій - Чорнобильської і Цвентендорфскої (неподалік Відня) 3 точки зору української літературознавиці і культурологині Тамари Гундорової: «Археологічна опера в семи новелах», як говориться в анонсі, розповідає про постсуспільство, у якому опиняються «нащадки людства» «після смерті капіталізму, опери i філософії». Метафора «антропологічного музею», мабуть, найкраще визначає природу такої «археологічної опери», де ідеться про спробу поселенців на місці колишнього Чорнобиля відживити, регенерувати втрачену цивілізацію через серію перформансів - прадавніх поганських піснеспівів, імітацій класичної опери, молитви-меси до Чорнобиля, поклоніння золотому Тільцю, фетишизації цифрової цивілізації. Захоплюючий і моторошний епізод ритуального дійства - поклоніння алгоритмічному фортепіану Rhea-player (винахід австрійця Вінфріда Рітча), що автоматично генерує музику, як новий Бог, що приходить на зміну людині». «Чорнобильдорф», або як катастрофа пише нами». Гундорова, Тамара. LB.UA. URL: https://lb.ua/culture/2020/11/24/471369_chornobildorf_abo_yak_katastrofa.html 
опери як «справжнього мультимедійного мистецтва, що, подібно до сучасного кіно, залучає у свій оперний простір найпередовіші технології освітлення, декорацій, театральної інженерії, не кажучи вже, власне, про сучасні мистецькі ідеї» ${ }^{47}$. Разом із тим Алла Загайкевич завершила оперу «Вишиваний. Король України» на лібрето знакового для української літератури митця Сергія Жадана - поета, прозаїка, есеїста, співака, музиканта українських рок-груп. Очевидно, що твір, який пропонує важливий історичний наратив у форматі літературної опери, представить i нову перспективу оперного вокалу, адже, як зауважила композиторка, в цьому масштабному «не стільки історичному, скільки ліричному» творі про Василя Вишиваного ${ }^{48}$ відбувся «пошук “нового голосу” опери». Очікується також і нова опера Юрія Ланюка «Чуже обличчя», що має відкрити ексклюзивний напрям літературноінтонаційного синтезу (в лібрето використані тексти японця Кобо Абе, німця Франца Кафки, француза Оноре де Бальзака).

У творчості визнаних сучасних західноєвропейських оперних композиторів Філіппа Гласса, Кайї Сааріаго, Аріберта Раймана, Вольфганга Ріма, Джорджа Бенджаміна, Сальваторе Шарріно, Джона Адамса, Йорга Відманна, Ольги Нойвірт, а також у операх молодих композиторів Віллема Джетса, Мирослава Срнка, Гауке Бергайде оперний вокал залишається провідним музичним стрижнем оперної драматургії. Не-оперний голос-тіло підключаються лише у якості доповнення. Наприклад, у мультимедійній опері «Орландо» на лібрето Ельфріди Єлінек ${ }^{49}$ центральну роль Орландо виконувала відома американська «зірка» - мецо-сопрано Кейт Ліндсі, а на роль їі сина був запрошений відомий кабаретист Justin Vivian Bond, відомий в Америці як автор трансгендерних перформенсів ${ }^{50}$. Попри відзиви опонентів, Ольга Нойвірт не зредагувала жодного такту партитури і вже вписала свою ореra summum в історію пост-, мета-, медіаарту. Баланс шоу,

${ }^{47}$ Sirenko L. «Де шукати сучасну оперу?» \#1: Алла Загайкевич та опера «Вишиваний». The Claquers. URL: https://theclaquers.com/posts/3766

${ }^{48}$ Василь Вишиваний - Вільгельм Франц Йозеф Карл фон ГабсбургЛотаринзький був ерцгерцогом 3 династії Габсбургів, полковником Легіону Українських Січових Стрільців і неофіційним кандидатом на український престол у разі встановлення монархії.

${ }^{49}$ Опера «Орландо» створена Ольгою Нойвірт за мотивами роману Вірджинії Вулф на замовлення Віденської Staatsoper.

50 Втручання не-оперних співаків і не-симфонічного інструментарію зустрічаються і в оперній класиці. У байройтській версії «Таннгойзера» Тобіаса Кратцера в перерві між актами заплановані виступи відомого перформансиста, нігерійського драг-артиста, рок-співака Le Gateau Chocolat, який грає роль одного 3 друзів Венери (Елена Жидкова). Режисер Анту Ромеро Нуньес включив в оркестрову тканину опери Дж. Верді «Бал-маскарад» технофрагмент, за що отримав гучні «Бу!» від опероманів. 
мюзиклу, квір-культури, літературної рефлексії, трансгендерного маніфесту зберігає суть оперного жанру, який авторка слушно визначила як hybride Grand Opera.

Нарешті останнє питання, стосується реакції самих вокалістів на сентенції про смерть опери або на оперу для homo videns. Як оперні вокалісти оцінюють трансформації вокалу в сучасній опері? Перспективи інновацій із вокалом у різновидах пост- $i$ квазіоперах вокалісти, котрі зробили успішну кар'єру за кордоном, не мають однозначної думки. Бесіди 3 деякими 3 них (Людмилою Монастирською, Софією Соловій, Зоряною Кушплер, Ольгою Дядів, Тарасом Конощенком, Михайлом Малафієм, Романом Чабаранком) свідчить про бажання сполучати партії репертуарних опер з оперними експериментами XX-XXI століття. Молода українська сопраністка Ольга Дядів поряд з операми Россіні, Моцарта, Доніцетті, співала партію Мари в камерній опері-фантасмагорії сучасної української композиторки Кармели Цепколенко «Доля Доріана» за мотивами роману Оскара Вайлда «Портрет Доріана Грея» (лібрето в українському перекладі: Сергій Ступак). У прем’єрі опери Максима Коломійця «Ніч» Ольга Дядів виконувала три ролі: хлопчика зі старою бандурою, внутрішній голос Марії (розмовні діалоги) та образ краси, втілений в арії Le ombre delle ceneri / Тіні попелу).

Репертуар українського баритона Тараса Конощенка, соліста Нюрнберзької опери, включає поряд із відомими партіями з опер I. Стравінського «Походеньки гульвіси» (The Rake's Progress) і Бенджаміна Бріттена «Пітер Граймс» (Piter Grimes) рідко виконувані опери Вернера Егка «Ірландська легенда (Irische Legende) і Кармелли Цепколенко «Доля Доріана». Молодий баритон Юрій Самойлов, соліст Франкфуртської опери, задіяний у партіях Біллі Бада і Принца фон Гомбурга 3 однойменних операх Бенджаміна Бріттена (Billy Budd) і Ганса Вернера Генце (Prinz von Homburg). Серед розмаїття оперного репертуару Софії Соловій (Альчіна в «Альчіні» Г.Ф. Генделя, Вітелія в «Милосерді Тита» В.А. Моцарта, Електра в «Ідоменеї» В. А. Моцарта, сопранові партії 3 «Еліаса» Ф. Мендельсона, партія Ельзи в «Лоенгріні» Р. Вагнера) обсяг сучасних творів від К. Пендерецького, Д. Моріарті, Ю. Ланюка включає оперу Маттео D’Аміко «Нерозуміння», (Le Malentendu, 2009) за мотивами п'єси Альбера Камю.

Українська мецо-сопрано Зоряна Кушплер, солістка Віденської опери заявила про себе в багатьох знакових постановках опер кінця XX-XXI століття. Серел них «Гоголь» Лєри Ауербах, «Три сестри» Петера Етвьоша, «Нора» Альбіна Фріза, «Верби» Йоганнеса Марія Штауда, «Медея» Аріберта Райманна, «Орест» Манфреда Трояна тощо. 
У згаданій опері Ольги Нойвірт «Орландо» Зоряна Кушплер асистувала Кейт Ліндсі. Співачка зауважила: «Кожна сучасна опера має свої особливості. Але завжди важливою запорукою успіху була концепція режисера і сценографа, а співаки були матеріалом. Погоджуюся на всі 100 , що голос співака в сучасній опері не $\epsilon$ вирішальним засобом, тим більше, якщо музика атональна, як наприклад, в опері Аріберта Райманна «Медея». У цій постановці я виконувала роль Гори. Дуже складна музика: в партії постійні стрибки, різки зміни регістрів, нервовий ритм. Показати красу власного тембру неможливо. Але за режисуру взявся італієць Карлос Мореллі і створив несамовиту сценічну естетику. Такого яскравого театрального дійства я ще не бачила! I ця постановка досі згадується не як опера Райманна, а як винятковий візуальний синтез Райманна і Мореллі. Якщо опери бароко, класицизму, романтизму можна прекрасно слухати в концертному виконанні, сучасним операм концертна практика протипоказана. Я переконана - сучасна опера живе в аурі перформенсу» ${ }^{51}$.

Натомість відповіді на запитання про майбутнє оперного вокалу в експериментальних проєктах із не-оперними голосами доволі суперечливі: «Експерименти мають відбуватися <..> добре, коли з'являються нові оперні проекти... із задоволенням долучився (долучилася) би до нових опер, але не хочу виходити за межі оперної кваліфікаиії <..> оперний голос не потребуе технічних пристроїв $i$ підсилювачів, оперний голос має здатність «линути понад оркестром» ${ }^{52}$.

Взаємообмін такими питаннями і відповідями працює на Тур де Форс у дослідженні сучасних анти- і постопер, не розібравшись у суті яких можна зупинити на ходу історичний потяг 400-вікової оперної історії. Оперний театр оперує досвідом передачі знань від майстра до учня, від минулого до майбутнього. Безперервність культурноісторичного процесу розвитку опери в іï історичних модифікаціях, ознаки рецепції homo audiens i homo videns - органічна складова частина європейської антропосоціології. Розвинуті держави, корпорації, фінансові компанії, меценати невипадково патронують оперну справу. Опера як явище гетерогенне, має високий соціокультурний статус, визначає інтелектуально-культурний рівень національної і державної ідентифікації будь-якої країни у світі.

\footnotetext{
${ }^{51}$ Кушплер 3. Сучасна опера живе в аурі перформенсу. Збруч. 2020. 2 вересня. URL: https://zbruc.eu/node/100030

52 Линути понад оркестром. Панкратова Елена: Щиро бажаю всім героїням майбутнє без пандемій i вірусів! Розмова перша. 2020. Збруч. 25 травня. URL: https://zbruc.eu/node/97873
} 


\section{ВИСНОВКИ}

Оперна традиція зберігає пам'ять поколінь і у цьому сенсі має безцінний виховний і творчий потенціал (в Україні поки що неналежно оцінений). 3 погляду історичної перспективи опера - це багатовіковий музично-театральний досвід, що впливає на освіту, виховання, передачу знань і вмінь від майстра до учня і визначає не лише рівень освіченості суспільної еліти, а й рівень демократії того чи іншого суспільства. В оперних постановках нашого часу оживає колективна творчість як засіб комунікації.

У всі часи театр оперував найновішими технологіями. Колористика сценографії, ефектні костюми, розраховані на активність homo videns, винайдені не сьогодні. Опера завжди взаємодіяла 3 хореографією або акробатикою, використовувала складну машинерію, що потребувала новітніх інженерних розробок. Отже, вагома роль технологій у сучасній режисерській закономірна.

Музиканти і музикознавці усвідомлюють, що квінтесенція опери як феномена не змінилася: опера - лідер мистецької ексклюзивності. Поряд із високим статусом симфонічного оркестру ексклюзивною $\epsilon$ культивована естетика оперного голосу - екстатика енергетично незмірного тренованого вокалу, відшліфованого протягом творчого життя. Оперний голос-тіло - феномен, зумовлений високим рівнем майстерності, віртуозності, сили психоемоційного впливу на публіку. І все це - нерозривні складники професіоналізму як наслідку багаторічної освіти і консеквентного саморозвитку ${ }^{53}$.

Моцартівський Директор театру з однойменної опери заповів нам справжню оперну істину: Oper ist mehr als „Auf den Brettern, die die Welt bedeuten stehen!". Oper ist viel mehr! Oper ist der Inbegriff der Leidenschaft! Oper ist die Nahrung unseres Geistes! Oper ist das Universum des Lebens! Oper ist die Überhöhung des menschlichen Daseins!

\section{АНОТАЦІЯ}

Розмаїття постмодерних мутацій жанру опери наочно демонструє оперна практика, яка ініціює нові ракурси наукового дослідження. Завдяки Regieoper зросли вимоги до оперних співаків. Натомість інтерес сучасних композиторів до оперних голосів почав поступово знижуватися. Радикальні квазіоперні проєкти молодих митців викликають інтерес. Але відкритим залишається питання перспективи оперних співаків у театрально-музичних проєктах майбутнього. Оперний вокаліст-актор вже не є primadonna і primouото (musico),

\footnotetext{
${ }^{53}$ Аналогічні характеристики стосуються співаків хору i музикантів симфонічного оркестру.
} 
а ланкою, яка стає значущою лише в загальній структурі сценічної постановки. Співак опиняється в центрі полісемантичних стосунків: актор - сценічний простір, актор - музично-драматичний текст, актор інші актори. Отже, метою статті став аналіз деяких наслідків деструкції жанру опери з позиції вокалістів і сучасних композиторів. Ставляться завдання вияснити відповіді на такі питання: 1) як перформативність змінила оперних артистів, 2) які фактори постановки стали імпульсом інтерактивності публіки, 3) які критерії дають змогу композиторам називати свої музично-театральні артефакти операми.

Актуальність дослідження результатів опери як семіотичного об'єкта зумовлена вимогами оперної практики. Дискусії навколо задумів, концепцій, техніки i взагалі суті квазіоперних проєктів із синтезом оперного вокалу 3 етноспівом або репом, симфонічної партитури з електро-, рок-, техно-засобами зростають, а музикознавці ще не виробили відповідної методики аналізу сучасних квазіоперних артефактів.

У статті здійснюється огляд найбільш рельєфних нині оперних проєктів сучасних композиторів. Також означені вектори взаємодії синтетичних музично-театрально-візуально-медіальних засобів. Паралельно розглядаються перспективи експериментального поєднання оперного і не-оперного вокалу.

Дослідження нових опер i квазіопер iз погляду соціологічного, комунікативного, медійного, навіть політичного результатів творчості випереджають оцінку мистецької значущості твору, адже остання потрібує випробування часом. Проте вектор вивчення оперної творчості українських композиторів у системі європейського антропосоціокультурного топосу пропонується в музикознавстві вперше.

Розвідки цієї статті довели, що суть опери як феномена розширилася, але не змінилася докорінно: опера залишається лідером мистецької ексклюзивності. Поряд із високим статусом симфонічного оркестру ексклюзивною $є$ i культивована естетика оперного голосу, а саме: екстатика енергетично незмірного тренованого вокалу, студійованого i відшліфованого протягом цілого творчого життя. Оперний голос-тіло (термін Е.) - феномен, зумовлений високим рівнем майстерності, віртуозності, сили психоемоційного впливу на публіку. I все це нерозривні складники професіоналізму як наслідку багаторічної освіти i консеквентного саморозвитку. 3 позиції історичної перспективи опера це багатовіковий музично-театральний досвід, що впливає на освіту, виховання, передачу знань і вмінь від майстра до учня і визначає не лише рівень освіченості суспільної еліти, а й рівень демократії того чи іншого суспільства, адже в оперних постановках нашого часу оживає колективна творчість як засіб комунікації. 


\section{SUMMARY}

The article is devoted to studying of destruction of the opera genre. The diversity of postmodern mutations in the opera genre demonstrated by opera practice, which initiates new perspectives on scientific research. Thanks to Regieoper, the requirements for opera singers have increased. Instead, the interest of modern composers in opera-voices began to reduce. Radical quasi-opera projects of young composer are of interest. However, the question of the perspective of opera singers in theatrical and musical projects of the future remains open. The opera singer-actor is no longer primadonna or primouomo, but a one of many component that becomes significant only in the general structure of the stage production. The singer is in the center of polysemantic relations: the actor - the stage area, the actor - the musicaldramatic text, the actor - other actors. Consequently, the object of the article was to analyse some of the consequences of the destruction of the opera genre from the point of view of vocalists and contemporary composers. The task is to find out the answers to the following questions: 1) how performativity has changed opera artists, 2) what factors of production have become the impetus for audience interactivity, 3) what criteria allow composers to call their musical and theatrical artefacts operas. The relevance of the study of the results of opera as a semiotic object is due to the requirements of opera practice. Discussions about ideas, concepts, techniques and, in general, the essence of quasi-opera projects with the synthesis of opera vocals with ethno-singing or rap, symphonic score with electro-, rock-, techno- means are growing, and musicologists have not yet developed appropriate methods of analysis of modern quasi-opera artefacts. The article reviews some contemporary opera projects of modern composers. Vectors of interaction of synthetic musical-theatrical-visual-media means are also marked. The prospects for the experimental combination of opera- and non-opera-vocals are compared.

Scientific novelty and research results. The study of new operas and quasi-operas from the point of view of sociological, communicative, media, and even political results of creativity is ahead of the assessment of the artistic significance of the work, because the latter requires a test of time. However, the vector of studying the opera of Ukrainian composers in the system of European anthroposociocultural topos is proposed in musicology for the first time. The research of this article proved that the essence of opera as a phenomenon has expanded, but has not changed radically: opera remains the leader of artistic exclusivity. Along with the high status of the symphony orchestra, the cultivated aesthetics of the operatic voice is exclusive, namely, the ecstasy of energetically immeasurable trained vocals, studied and honed throughout the creative life. Opera voice-body (Jelena Novak) is a phenomenon caused by a high level of skill, virtuosity, and the 
power of psycho-emotional influence on the audience. And all these are inseparable components of professionalism as a consequence of many years of education and consistent self-development. From the historical perspective, opera is a centuries-old musical and theatrical experience that influences education, upbringing and transfer of knowledge and skills from master to student and determines not only the level of education of the social elite, but also the level of democracy of a society. After all, in the opera productions of our time, collective creativity comes to life as a means of communication.

\section{ЛІТЕРАТУРА}

1. Carrera, Martino. La Scala's Costumes Exhibition Bows in Milan. On October 16, 2017. WWD. Fashion. Beauty. Business. URL: https://wwd.com/fashion-news/fashion-scoops/la-scala-costumesexhibition-bows-milan-11028383/

2. Die Zukunft der Oper. Zwischen Hermeneutik und Performativität. Herausgegeben von Barbara Beyer, Susanne Kogler und Roman Lemberg. Berlin: Theater der Zeit. Recherchen 113. 430 S. ISBN 978-3-943881-88-2.

3. Гундорова Т. «Чорнобильдорф», або як катастрофа пише нами». LB.UA. URL: https://lb.ua/culture/2020/11/24/471369_chornobildorf_abo_ yak_katastrofa.html.

4. Сфіменко А. Музичні рейтинги IV. Збруч. 2020. 31 грудня. URL: https://zbruc.eu/node/102505

5. Загайкевич А. Мультимедійне мистецтво, яке залучає найпередовіші технології. Ukrainian Time. 26.03.20 / 05:41. URL: https://ukrainiantime.org/uk/article/multymediine-mystetstvo-yakezaluchaie-naiperedovishi-tekhnolohii

6. Husserl, Edmund. Husserliana. Gesammte Werke, Bd 10. Zur Phänomenologie des innerem Zeitbewusstsein (1893-1917). S. 19-72.

7. Іваницька Я. Оперна вистава як семіотичний об'єкт : дис. ... канд. наук : 17.00 .03 «Музичне мистецтво». Національна музична академія України ім. П.І. Чайковського, Київ, 2008.

8. Карпенко, Лідія. «Чернобильдорф» - археологія майбутнього. Українськи правда / Життя. 3 грудня 2020. URL: https://life.pravda.com.ua/columns/2020/12/3/243254/

9. Кушплер 3. Сучасна опера живе в аурі перформансу. Збруч. 2020. 2 вересня. URL: https://zbruc.eu/node/100030

10. Lehmann, H. Die Kunst der reflexiven Moderne / Orientierungen: Wege im Pluralismus in der Gegenwartsmusik. Die Veröffentlichungen des Instituts der Neue Musik und Musikerziehung Darmstadt: Schott Band 47. S. 24-44. 
11. Матт Г., Флатц Т., Льодерер Ю. Культура i гроші. ВП «Юніверс» / пер. О. Кислюк. 2009. С. 7. ISBN 978-966-8118-71-5.

12. Мигашко О. Ілля Разумейко та Роман Григорів про Chornobyldorf: «Ми займаємось мистецькою некрофілією». Yabl. URL: https://yabl.ua/2020/11/07/illya-razumejko-ta-roman-grigoriv-prochornobyldorf-mi-zajmayemos-misteckoyu-nekrofiliyeyu

13. Morabito, S. Die tollkühne Tour de force einer spielerischen Dynamisierung der fixierten Partitur (über Dramaturgie im Musiktheater). Regie für ein Haus. Vortrag für Auftakt! Der Oper Stuttgart am 17.9.2017. URL: https://www.yumpu.com/de/document/read/21636705/1-regie-fur-einhaus-vortrag-von-sergio-oper-stuttgart

14. Novak, J. Einstein on the Beach: Opera beyond Drama (co-edited with John Richardson). 2019. Routledge-Verlag. 350 p. ISBN 9781472473707.

15. Novak, J. Operofilia 2018. Belgrade: Orion Art. 182 p. ISBN 8663890885.

16. Novak, J. Postopera: Reinventing the Voice-Body. 2015. RoutledgeVerlag. 192 S. ISBN: 978-1-4724-4103-4.

17. Парин А. Прощание с Оперой Ивановной. Журнал ТЕАТР. 2012. № 6-7. ISBN 0131-6885.

18. Подорож до Антарктиди. Euronews. 04.02.2016 URL: https://ua.euronews.com/2016/02/04/journey-to-the-antarctic

19. Risi,. Die Stimme in der Oper zwischen Mittel des Ausdrucks und leiblicher Affizierung / Die Zukunft der Oper. Zwischen Hermeneutik und Performativität. Herausgegeben von Barbara Beyer, Susanne Kogler und Roman Lemberg. Berlin: Theater der Zeit. Recherchen 113. S. 272-273. ISBN 978-3-943881-88-2. S.267-275.

20. Сисенко А. Чорнобильдорф - постапокаліптичні пошуки опери. Музика. 2021. 27 січня URL: http://mus.art.co.ua/chornobyldorfpostapokaliptychni-poshuky-opery/

21. Sirenko L. «Де шукати сучасну оперу?» \#1: Алла Загайкевич та опера «Вишиваний». The Claquers. URL: https://theclaquers.com/ posts $/ 3766$

22. Sirenko L. Де шукати сучасну оперу? \#9: Роман Григорів, Ілля Разумейко | Nova opera та «Чорнобильдорф». The Claquers. 17.9.2020. URL: https://theclaquers.com/posts/4437

23. Sirenko L. «Опери» кандидата в президенти США Каньє Веста. The Claquers. URL: https://theclaquers.com/posts/3851

24. Sirenko L. The Claquers. Подкасти. URL: https://theclaquers.com/ posts/category/podcast 
25. Терещук Г. Опера-міф «Ukraine - Terra Incognita»: Радіо Свобода. 10 серпня 2020, 12:37. URL: https://www.radiosvoboda.org/a/ ukraine-terra-incognita/30775399.html

26. Vick G. Atme das Leben. URL: http://operavision.eu/de/bibliothek/ auffuehrungen/opern/fidelio-birmingham-opera-company\#einblicke

27.7 Deaths of Maria Callas, München - Turandot, Lviv Opernprojekte, IOCO Essay, 18.02.2021.

28. Браун С. Из другой оперы: художник в роли постановщика. The Art Newspaper Russia. 2020.18 сентября. URL: http://www.theartnewspaper.ru/posts/8401/

29. Панкратова Е. Щиро бажаю всім героїням майбутнє без пандемій i вірусів! Розмова перша. Збруч. 2020. 25 травня. URL: https://zbruc.eu/node/97873

\section{Information about author:} Yefimenko A. H., Doctor of Art History, Professor at the Department of the History of Music Lviv National Music Academy named after Mykola Lysenko 5, Ostapa Nyzhankivskoho str., Lviv, Ukraine Professor at the Faculty of Philosophy Munich Ukrainian Free University 9A, Barellistr., Munich, Germany 